家畜育種における長期的な選抜の効果の予測

\author{
西田 朗
}

農林水産省畜産試験場，茨城県筑波農林研究団地 305

\title{
Prediction of Long-term Selection Response in Animal Breeding
}

\author{
Akira NisHIDA \\ Natiomal Institute of Animal Industry, Tsukuba \\ Norinkenkyudanchi, Ibaraki-ken 305
}

Key words : prediction, long-term selection, selection response, animal breeding

\section{I. 問題の所在}

育種家が選抜による効率的な育種計画を立てるために は，各種の選抜法の長期的な効果を予測して比較できな ければならない，現在，短期の効果はある程度予測でき る. しかし，長期的な選抜の効果の予測能力は不充分て あり，理論と方法の改善が必要である ${ }^{14,15)}$.

\section{II. 短期的な選抜反応の予測法とその問題点}

1 回の選抜による遗伝的改良量 $\Delta \mathrm{G}$ の予測値は，選 抜差 $\mathrm{S}$ と遗伝率 $\mathrm{h}^{2}$ の積で求められる.

$$
\Delta \mathrm{G}=\mathrm{Sh}^{2}
$$

この改良量が，かなり長い世代にわたって続くことも あるが，選抜により菄団の性質が变化するので，正しく は，この予湘は 1 世代限りのものである ${ }^{13,68)}$ 。また，特 に選抜の進んだ段階では，この1世代限りの予测も実現 值と合わない場合のあることが知られている.

上下二方向への選抜では，しばしば，非対称な選抜反

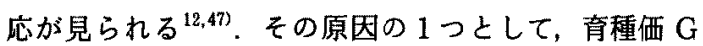
の表型価 P に対する回畄が曲っていることが考えられ た. そこで，実際にこの回㳏は直線とみなし得るか否か が調べられだ2。 その結果，回帰が直線の場合と ${ }^{1,5,58),}$ 曲線の場合とがあった がひずむことは以前から知られていたので,30,699，これ
が回帰の曲線性の原因ではないかと考えられた。

NISHIDA and $\mathrm{ABE}^{44)}$ は， G および環境効果 $E$ の分 布のひずみと, $\mathrm{G} の P=G+E$ に対する回带の型との 関係を数值実験で調べた。その際，GとEの分布を同 じべき（n）をむつ2項分布 $(\mathrm{p}+\mathrm{q})^{\mathrm{n}}$ で表わし， $\mathrm{p}$ を 変えてひずみの強さを調節した，その結果は，つぎのと おりである.ここで，例えば $\mathrm{G}$ の分布のひずみ倸数を $\mathrm{SK}_{\mathrm{G}}$ と書く. $\mathrm{SK}$ は分布の 2 次のモーメント $\mu_{2}$ に対 する 3 次のモーメント $\mu_{3}$ の比の関数で，0なら対称分 布，正なら右，負なら左へ尾を引く分布之なる。

1. $\mathrm{SK}_{\mathrm{G}}=\mathrm{SK}_{\mathrm{E}}$ なら $\mathrm{G}$ の $\mathrm{P}$ に対する回帰は直線と なる.

2. $\mathrm{SK}_{\mathrm{G}}>\mathrm{SK}_{\mathrm{E}}$ なら回帰は下に凸な曲線となる.

3. $\mathrm{SK}_{\mathrm{G}}<\mathrm{SK}_{\mathrm{E}}$ なら回帰は上に凸な曲線となる。

4. $\mathrm{SK}_{\mathrm{G}}$ と $\mathrm{SK}_{\mathrm{E}}$ の差が大きいほど，回帰の直線か らのずれが大きい。

ROBERTSON ${ }^{64)}$ は， GのP に対する回㷌の曲線性に ついて理論的に研究した。そとして，曲線回帰の 2 次の項 の係数の符号は， Gと Eそれぞれの分布の $\mu_{3}$ の $\mu_{2}$ に対する比の差

$$
\left(\mu_{3} / \mu_{2}\right)_{G}-\left(\mu_{3} / \mu_{2}\right)_{\mathbf{E}}
$$

の符号上一致することを示した，彼は，このことは， LINDLEY $^{38)}$ が示した「あし $\mathrm{y}=\mathrm{x}+\mathrm{w}$ で, $\mathrm{x}$ と $\mathrm{w}$ が 独立に分布し， $\mathrm{x}$ の高次モーメントが $\mathrm{w}$ のそれの倍数 
になっていれば，xの $\mathrm{y}$ に対する回帰は直線である.」 という事害の特例であるとした，さらに彼は，NISHIDA and ABE の結論は LINDLEY の示した代数的な事実を 遗伝的に表現したものであるとした。

NISHIDA and ABE はさらに, G のP に対する回兴 が曲っているときに，その情報を選拔反応の予測に活用 する方法を示しだ．また，分布のひずみによる回帰の 曲線性が，二方向選抜の非対称選抜反灾の原因となるこ とを明らかにしだ?

\section{III. 長期的な選抜反応に影䉕を与える要因}

長期的な選拻反応に影響を与える要因としては，つぎ のむのが考えられる。

1. 育種家が決定できる要因
(1) 選抜の指標
（2）集団の大きさ
(3) 選抜率または選抜強度
(4) 交配法

2. 育種家がある程度コントロールでき，基礎集団で 推定できる要因

（1）関心のある形質の平均値，表型分散，遗伝分散, 遺伝率または選抜の正確度，形質間の表型およ び遣伝相関

（2）個体の近交係数之個体間の血縁関係の強さ

（3）選抜環境の影響

3. 基礎集団では推定できない要团

（1）関心のある形質に影響を与える遺伝子の数と各 遺伝子の効果および頻度

（2）それらの遭伝子間の交互作用（上位性効果）

（3）連銷不平衡で生じる道伝子間の相関

(4) 一定方向人の選抜に対抗する目然沟汰の强さ

(5) 新しい笑然変異の発生率とその効果の分布

以下に，これらの要因の選抜反応への影響に関する研 究をあげる。

・選抜の指標に関する研究 1-(1) :

育種価の推定については，現在，㕕く使われている BLUP 法にいたる重要な研究の分野があるが16)，ここ では触れない。

・菓団の大きさに関する研究 1-(2)：

ROBERTSON や HILL はこの問題について一連の研究 を行ないつぎのことを示した。

1）後代検定之家系選抜計画に枋ける最適グループサ イズと選抜されたグループの遺伝的な優秀さは（毎世 代測定される個体数)/(選抜する父または家䒺グループ 数）之遺伝率ならびにグループ内個体間の血縁度により 決まる ${ }^{57 ?}$.

2）無選抜，無作為交配の集団における連鎖した優性
効果をむつ邀伝子のモデルでは，采統内分散の式に連鎖 不平衡の項が含まれていた，遇鎖不平衡は系統内にチャ ンスで起こり，集団の有効な大きさ $N$, 染色体の全長 ならびに幍伝子数で決まる，関与する遗伝子座の数が多 ければ，この連銷不平衡は系統内の分散を大巾に增加さ せる゙

3） N の選抜の効果に対する影蔇は 5 世代までは小 さいが，それ以降，次第に重要となる．Nを大きくす ることの意義は，近親交配の抑制や初期に良い遗伝子を 失なうのを防ぐことではなく，選抜が進むにつれて，突 然変異から生じる新しい分散を活用することにある ${ }^{25)}$.

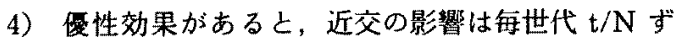
つ直線的に增大する．ただし $\mathrm{t}$ は世代数である. 相加 的で非常に小さい逶伝子効果のモデルでは，初め $\Delta \mathrm{G}$ 之相加的遗伝分散 $\mathrm{V}_{\mathrm{A}}$ は $(\mathrm{t} / \mathrm{N})^{2} \mathrm{~V}_{\mathrm{A} 0}$ に比例して低下 し, 突然变異で $t^{2} V_{m}$ に比例して増大する. ただし， $\mathrm{V}_{\mathrm{A} 0}$ は基礎集団にお污る相加的遗伝分散， $\mathrm{V}_{\mathrm{m}}$ は突然 変異で生じる世代あたりの新しい分散である。結局，突 然変異にむとつく $\Delta \mathrm{G}$ は $\mathrm{NV}_{\mathrm{m}}$ に比例して增加する。 $\mathrm{N}=10 \sim 160$ の範囲では， $\mathrm{N}$ が 5 世代までの選抜の効果 に与える影響は小さいが，10世代以降は重要となる. 育種家が選抜計画のために使える時間の長さが， $\mathrm{N} の$ 選択に大きく影響する

5）切断選抜を行なう相加的モデルでは，笑然変異と ドリフトの均衡で達成される分散の大きさは, 選抜強度 i とは独立であるが $\mathrm{N}$ に比例する. 定常化選拔で保持 される分散は N が小さいときだけ $\mathrm{N}$ に比例する. 自 由に組換えが起きるときに，N が大きくなるとこの分 散は，笑然变異の数に比例して決まる漸近線に近づく ${ }^{29}$.

6）実験の全体の規模を大きくすることにより，選抜 による $\Delta \mathrm{G}$ の変動係数は小さくなる23).

7）小規模な選抜実験での効果の変異は大きく，これ による推定は信頼できない，第 $\mathrm{t}$ 世代の家畜の親とな った集団の平均值 $\mathrm{Zt}$ の分散 $V(\mathrm{Zt})$ は, $\mathrm{t} / \mathrm{N}$ に比例す $3^{22)}, \mathrm{V}(\mathrm{Zt})=(\mathrm{t} / \mathrm{N}) \mathrm{V}_{\mathrm{A} 0}$.

8）選扳系統における $\Delta \mathrm{G}$ は，系統の基礎を作った 家畜の標本の大きさに依存する，相加的な遺伝子効果を あつ 1 座位について，基礎畜の数が初期の $\Delta \mathrm{G}$ と選抜 の限界に与える影響を調べたところ，基礎畜の数が減る と全改良量も減少することがわかった，大きな集団に強 い選抜を加えたときに，この減少量が最大であった，少 ない基礎畜で作った系統の $\Delta \mathrm{G}$ は，やや多い基礎畜で 作った系統のそれよりも変異が小さかった

- 選抜強度に関する研究 1-(3) :

1）YouNG は大集団の選抜による改良をコンピュー 


\section{長期的な選拔の効果の予測}

タでシミェレートした，集団の大きさは 1000 個体/世代 で, $\mathrm{i}$ と $\mathrm{h}^{2}$ および組換率は各々 3 水準に変化させた。 相加的モデルでは世代ごとの $\mathrm{i} と \mathrm{~h}^{2}$ による $\Delta \mathrm{G}$ の推 定值は実現值とよく一致した， $\mathrm{h}^{2}$ が低いときに強い選 抜を加えると $\Delta \mathrm{G}$ 推定の正確度は少し下った，優性モ デルでは $\Delta \mathrm{G}$ の予测は不正確であった，選拔が強いと きには $\Delta \mathrm{G}$ の予測值は過大であり，弱いときには，わ ずかに過小評価された，選抜が強く $\mathrm{h}^{2}$ が高いときには 特にどちらのモデルでも $\mathrm{V}_{\mathrm{A}}$ の減少が急速であった。 連敛の影響は常に小さかった．このように大きい集団に 強い選抜を加えたときには，望ましくない対立遗伝子の 固定はみられなかった22.

2）ROBERTSON は個体選抜に関する理論的矿究と, コンピュータシミュレーションを行ない，選抜率 $\mathrm{p} を$ 世代とともに次第に落とすと，一定にしたときより $\Delta \mathrm{G}$ が増すことを見出した．選抜計画全体で測定でき る個体数が限られていて, 計画に要する期間が変えられ るなら，他のパラメターに独立に $\mathrm{p}=0.27$ が最善であ る、毎世代，測定する個体数が可变なら，各世代の測定 する個体数を時間とともに直線的に減らすことにより， $\Delta \mathrm{G}$ を $12 \%$ 增すことができる ${ }^{63}$.

3）選抜に上る $\Delta \mathrm{G}$ の変動係数は，選抜强度が中位 のときに最大值をとり，選抜強度がをれより弱くても強 くてあ改良量のばらつきが大きくなる23.

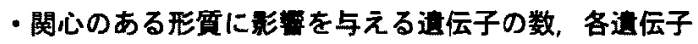
の効果および頻度についての研究 3-(1)：

1）定常化および二方向選抜の効果を，遭伝子頻度の 変化とハーディワインバーグの平衡かのずれ，ならび に連鎖不平衡の 3 種類の遺伝的变動で示すと， 1 番目と 3番目の変動が重要であった，選抜により連銷不平衡が 生じ，その結果，遺伝分散が定常化選抜では大きく急速 に減少し, 二方向選抜では同滕に増大した。

2）現行の計量遭伝学の制約は、，各種のパラメ夕ーを 用いても，厳密には，1世代限りの選抜反応しか予測で きないことである．より長い期間の反応は，関与する道 伝子の効果の分布之道伝子頻度に依存するが，これらの 情報はショウショゥバエについて少しあるだけで他の品 種ではない，相加的遺伝分散は遺伝子の効果之頻度に強 く依存している22).

3）トゥモロコシの脂肪之蛋白質の含有率に 76 世代 にわたる選拔を加えたところ，雨形質ともに相加的遺伝 標準偏差の 20 倍以上の予想を上回る $\Delta \mathrm{G}$ を示したが, 遗伝分散はまだ残っていた，考元うる遺伝子座の数之遺 伝子頻度を想定して，理論的な選抜の限界を評価してみ ると，この集団平均はまだ限界に達していなかった，新
しい方法で推定した望ましい遗伝子の初期頻度は脂肪の 率で 0.25 より低く，蛋白質の率で 0.37 より低かった。 高系統之低系統の脂肪および蛋白質の率の差に関与する 遺伝子座の数は, 各々最少で 54 と 122 と推定された。 脂肪の率に関する遣伝子にはかなりの優性効果がみられ $た^{10)}$.

- 連鎖不平衡およひ組換え率に関する研究 3-(3) :

1） HILL は，N と組換元率が一組の遺伝子座間の連

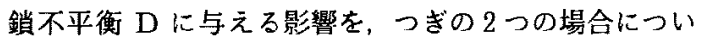
て調べた。

i）両座とも適応度に影響を与えない場合，

ii）へテロ接合体が優れているが，上位性効果はな い場合。

なお，2つの座位に各々 $A_{1}, A_{2}$ と $B_{1}, B_{2}$ の対立遗 伝子があり，例えば $\mathrm{f}\left(\mathrm{A}_{1}, \mathrm{~B}_{1}\right)$ は $\mathrm{A}_{1}$ と $\mathrm{B}_{1}$ をむつ配 偶子の頻度であるとすれば, $D=f\left(A_{1}, B_{1}\right) f\left(A_{2}, B_{2}\right)$ - $f\left(A_{1}, B_{2}\right) f\left(A_{2}, B_{1}\right)$ で求められる。它し集団が初 めに連鎖不平衡にあれば，近交をしてあ D の平均は 0 にとどまる。しかし， $\mathrm{D}^{2}$ の平均纳最大值にまで增加し たのち，両座位が固定するまで減少する，連銷と選抜が ともに強いと， $\mathrm{D}^{2}$ の平均が最大值に達する時期が荤れ， その值は大きくなることがわかった

2）選抜，突然変異ならびに連鎖の共同作用の下では， 連鎖により集団の道伝子型価の分布は下方へひずみ， $\Delta \mathrm{G}$ 上平衡遭伝分散は不平衡が重要になるにつれて小 さくなる．突然変異による分散が，小さな効果をもつ多 くの遗伝子でおきているとき，また，哭然変異の主な部 分が形質の測定值を増大させているときには，連鎖の効 果は大きい，なぜなら，大きな効果の遭伝子や有害な遦 伝子は，長いあいだ分離することがないからである34.

・選抜の効果と自然淘汰に関する研究 3-(4)：

1） KIMURA and CROW は，ある遭伝子の選択上の 優越度を求める式を示し，適応度関数之切断選抜との関 連などについて研究した ${ }^{9,36)}$.

・新しい突然変異にもとつく選抜反応の予測に関する研 究 ${ }^{28,35)} 3^{-}(5)$ :

1）最終的な選抜反応の速度は，世代あたりり突然変 異により起きる分散の和に依存する，また，突然变異効 果のばらつきが大きいほど, 初めの反応量と反応速度の 変異汃大り，大集団では，初如終りの反応速度の差 が著しい，新しい突然変異が，20 世代ぐらいまでに， 選抜の効果に大きな影響をすつことはないが，それ以後 は選拔の限界を高めるなど，かなりの貢献をすると考え られる。しかし，笑然変異による分散の情報は，ほとん どすべてショウジョウバエの剛毛数に関するものであっ 
た．大集団を使った育種計画を立てるときには，特に， 新しい哭然变異の役割を考えるべきである ${ }^{24)}$.

2）切断選抜を行なう相加的モデルにおいて，笑然 異がまれで，大きな効果をもつときには，連鎖は分散に あまり影響を与えないが，それが頻繁で小さな効果をむ つと，より強く影響する，突然变異を起こした遺伝子の 適応度への影響を考えると，集団平均が選抜の限界に漸 近する速度は大きく変るが，保たれる分散の大きさはあ まり変化しない299.ただし，梁然变異した䕗伝子は常に 適応度を下げるものとする。

これまでにあげた研究の他に，長期的な選抜反応の予 测に重要な関連をもつ,つぎの研究がある。

\section{・選抜による集団平均と分散の変化の型に関する研} 究 $^{7,61,66)}$ :

1）JAMES 加指数関数之放物線の回帰を 4 つの選抜 実験の反応曲線にあてはめたところ，常に指数関数のあ てはまりの方が優れ，初めに行なった選抜限界の推定は， 信頼性が低かっだ1).

2）初めの遺伝分散が，非常に多くの座位により作ら れていれば，集団平均の世代にともなう変化は上に凸な 曲線となり， $\mathrm{V}_{\mathrm{A}}$ のそれは下に凸な曲線となる ${ }^{65)}$.

- 選抜の限界に関する研究 ${ }^{11,19,73)}$ :

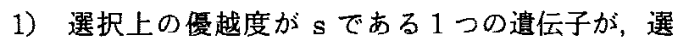
拔で固定する確率はNs の関数である，個体選抜の限 界は $\mathrm{Ni}$ が小さりれば， $2 \mathrm{Nih} \sigma_{\mathrm{C}}$ となる， $\sigma_{\mathrm{G}}$ は遺伝標 準偏差である. 相加的な効果をるつ道伝子については, $\Delta \mathrm{G}$ が可能な綕改良量の $1 / 2$ に達するのに $1.4 \mathrm{~N}$ 世代 以上を要することはなく，低い頻度の劣性遺伝子ではそ れが $2 \mathrm{~N}$ 世代となる。両性におけるi が等しい個体選 抜では，選拔率が $1 / 2$ のとき，最高の限界に達する．血 縁個体の情報む用いて選抜すると常に，初期の急速な改 良により選抜の限界が低下するが，大きな集団ではこの 損失は少ない

2）前に選抜の限界は $2 \mathrm{Nih} \sigma_{\mathrm{G}}$ であるとしたが，こ れは，組換えにより毎世代，連鎖不平衡が完全に除かれ ると仮定したので，過大評価であった ${ }^{65}$.

3）小集団における 2 つ座位を考えると，それらの 連銷の影響は 2 つの遺伝子座が選抜形質に対してほぼ等 しい奻果をすつときにだけ重要である. 両座位での固定 の確率が 0.7 と 0.8 の間にあるときに，連銷の改良量に 対する効果が最大となる，その効果が最大のときに，組 換え率を 2 倍にしても選拔による改良量は，わずかに 6 \%しか增加しない，個体選抜で最大の改良量を与える 選抜率は 0.5 であるが，連鎖が重要な働きをするときに はこれがわずかに高まる゙7?.
4）理論的な考察とシミュレーションの結果, 選抜第 $\mathrm{t}$ 世代の集団のパラメターは $\mathrm{Nih}^{*}, \mathrm{Nl}$ ならびに $\mathrm{t} / \mathrm{N}$ の関数となった ${ }^{62)}$. ただし， $\left(\mathrm{h}^{*}\right)^{2}$ は問題にしている染 色体で説明される表型分散の割合で，Iはその染色体の 長さ（モルガン）である，選抜の限界について，自由に 組換えが起きる場合の值 $\mathrm{L}_{\mathrm{f}}$ と, 全く起きない場合の値 $\mathrm{L}_{0}$ を比べ，つぎの結諭を得た。

i) $\mathrm{Nih}^{*}$ が小さいと $\mathrm{L}_{\mathfrak{f}} / \mathrm{L}_{0}=1+\frac{2}{3}\left(\mathrm{Nih}^{*}\right)^{2}$ と なる。

ii） $\mathrm{Nih}^{*}$ が増大すると， $\mathrm{L}_{\mathrm{f}} / \mathrm{L}_{0}$ は $2 \mathrm{Nih}^{*} / 3$ に近 づく.

iii）すしL $\mathrm{L}_{1}$ が中程度の組換え率における限界であ るとして，Nl が小さければ $\mathrm{L}_{1} / \mathrm{L}_{0}=1+\mathrm{N} 1 / 3$ となる. また近似的に $\mathrm{L}_{1} / \mathrm{L}_{0}=\frac{1}{3} \mathrm{KNl} /\left(\frac{1}{3} \mathrm{Nl}\right.$ + $\mathrm{K})$ となる.ただし， $\mathrm{K}=\mathrm{L}_{\mathrm{l}} / \mathrm{L}_{0}$ である。 したがって， $\mathrm{L}_{\mathrm{f}}$ と $\mathrm{L}_{0}$ の中間点を与える Nl または 1 の値は $\mathrm{Nl} \approx 3 \mathrm{~L}_{\mathrm{f}} / \mathrm{L}_{0}, 1 \approx 2 \mathrm{ih}^{*}$ となる。

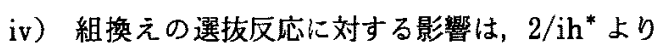
前の世代では，めったに表われない年．

\section{・選抜計画における近親交配の研㕤：}

1）人為選抜の下にある集団では， $\mathrm{N}$ は実際に選抜 される再親の数より小さいはずである，なぜなら，選抜 されている形質について家系閒に变異があるので，選抜 される確率に差が生じるからである，この効果は選抜が 強く選抜形質の $\mathrm{h}^{2}$ が高いほど大きい，特に目立って繁 殖に使用される個体による近交度の上昇は，それを用い てから数世代後に表われる ${ }^{60)}$.

・選抜実験の計画とコントロール集団の意酸に関する研 究:

この分野では HrLLが一般的な理論とコントロール 集団の設計20) ならびにコントロールを用いた実験の詳 細なレビューを発表している21)。また，FALCONER が コントロール集団についての情報をまとめて紹介してい る $^{13)}$.

\section{IV. 三種類の長期的な選抜の勃果の予測モデル}

\section{ここでは，最近に研究された三つのモデルを紹介する.}

1. 育㮔価 $\mathrm{G}$ 亡環境効果 $\mathrm{E}$ の同時分布を用いるモテル $\mathrm{G}$ を $\mathrm{y}$ 軸， $\mathrm{E}$ を $\mathrm{x}$ 軸とする直交座標系を考えると， 表型価 $\mathrm{P}=\mathrm{G}+\mathrm{E}$ の軸は $\mathrm{E}$ 軸を逆時㖕回りに 45 度だ け回転したものとなる（図 1).なぜなら，(G，E）平 面上で $\mathrm{P}$ が一定の值 $\mathrm{C}$ となるようなグラフ $\mathrm{G}+\mathrm{E}=\mathrm{C}$ を考えると，それは $\mathrm{G}=-\mathrm{E}+\mathrm{C}$ となり，傾きがー1 の直線であることがわかる.このグラフ上の点はすべて $\mathrm{P}=\mathrm{C}$ であるから，このグラフを投影したときに，そ 


\section{長期的な選拔の効果の予測}

の影が 1点に集中する軸が P 軸である，それは明かに G $=-\mathrm{E}+\mathrm{C}$ 上直交する直線であるから，上の結果が導 かれる ${ }^{45)}$.

この座標系での P による切断選抜とは， G と E の 同時分布 $\mathrm{F}(\mathrm{G}, \mathrm{E})$ を $\mathrm{P}$ 軸と直交する切断線の上に垂 直に立つ平面で切り取ることにあたる，切り取られた部 分を $\mathrm{G}$ 軸に投影すると，選拔された集讨の $\mathrm{G}$ の分布 $f(G)$ が得られる(図 1$)^{48)}$.

$$
f(G)=\int_{S} F(G, E) d E
$$

ただし， $\mathbf{s}$ は積分の範囲を選抜された部分に限ることを 意味する.

こうして得た $\mathrm{f}(\mathrm{G})$ を用いて新しい世代の $\mathrm{F}(\mathrm{G}, \mathrm{E})$ を作り，同じ操作をくり返せば，Gの分布の選抜によ る変化を考慮した長期的な選抜の効果の予測ができ

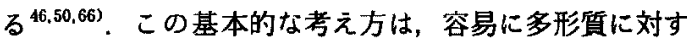
る選抜の効果を予测するモデルへと拡張できる ${ }^{49,51.52)}$.

このモデルによる数値例を作るにあたり，問題を簡単 にするためにつぎの仮定を㯰いた。

1）遺伝子の效果は相加的である.

2）すべての遗伝的な性質は，選抜された親の集団之 その子の集団で同一である.

3） $\mathrm{G}$ と $\mathrm{E}$ の同時分布は，一定の水準の等頻度曲線 の内側に限定する.

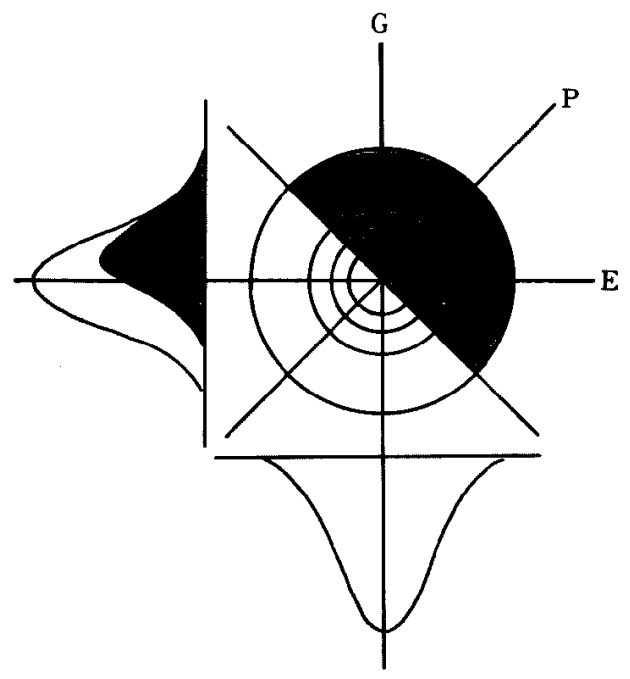

図 1. 表型価 P に上る切断選抜 $\mathrm{G}$ : 育種価, E : 環境効果, 斜線部は選抜された部分, 円は $\mathrm{G} と \mathrm{E}$ の同時分布の等頻度線
4） E は 3）の制限内で常に標準正規分布をする.

5）基礎集団での G は正規分布する.

6) $\mathrm{G}$ 上 $\mathrm{E}$ は独立である.

7）選抜率は 0.5 とする.

これらの仮定にもとづく数值例の一部を図 2,3 に示 した.これらの例は，選抜の最も基本的な効果を明らか にしてはいるが，上の仮定には問題がある．まず，2） は㛜密には成り立たない，選拔が加わっているときには， 繁殖により親の集団とその子の集団の遺伝的性質に差が 生じるからである，そこで，この差を評価するモデルを 作った ${ }^{71)}$.このモデルは関与する遗伝子座と対立遺伝子 の数，各遺伝子の効果と頻度を仮定した離散モデルで,

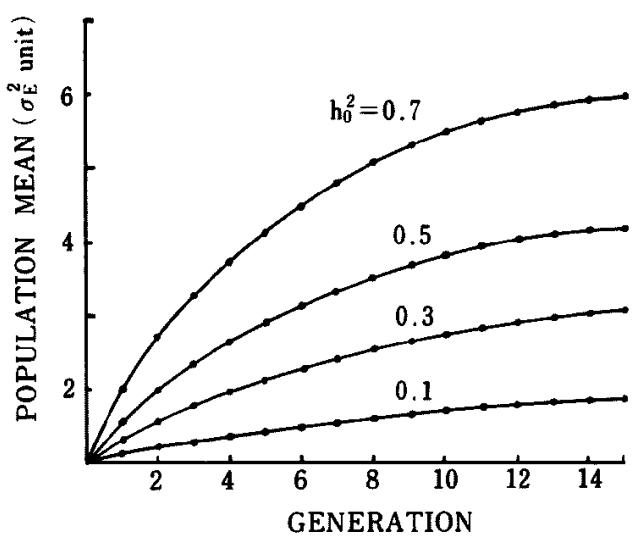

図 2. 切断選抜による集団平均の变化 $\mathrm{h}_{0}{ }^{2}$ : 基礎集団におりる遗伝率

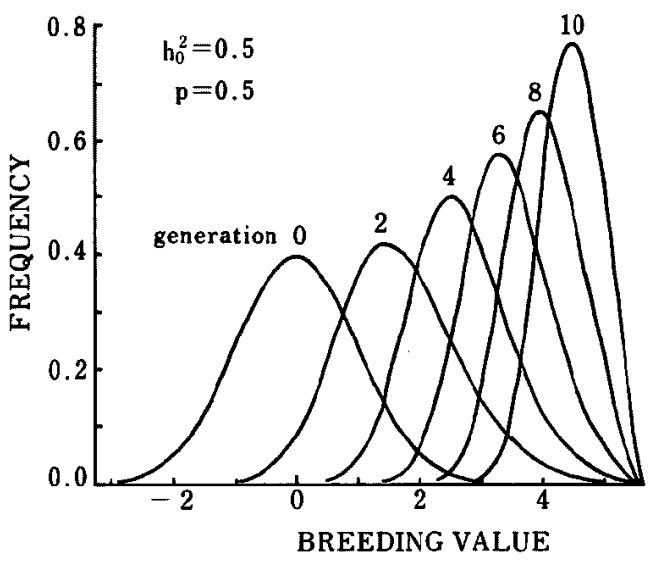

图 3.切断選抜による育種価の分布の変化 $\mathrm{h}_{\mathrm{0}}{ }^{2}$ : 基礎集団におりる透伝率 $\mathrm{p}$ : 選抜率 
減数分裂による配偶子の生産と交配によるそれらの再結 合を忠実にたどるすのであった，さらにこれを踏まえて， 速続分布でこの過程を近似するための方法を示した ${ }^{53,54)}$. これらの研究でも， $\mathrm{G}$ と $\mathrm{E}$ の同時分布を $\mathrm{P}$ で切断す る基本モデルは，そのまま活用された．また，連続分布 のモデルで，実際にこの予湘法を用いるには，選抜の限 界を正しく設定する必要があり，その方法に検討す心゙き 点が残されている.

ここに述べた予測モデルの基本的な考え方は簡明で一 般性の高いものである．今後もこれを，家畜有種の現場 で事前に容易に入手できる情報に立脚して，一層正確な 予測を可能にするモデルへと発展させなりればならない。

\section{2. 迹伝子の効果と頻度の同時分布を用いるモテル27)}

まず，記号をつぎのように定㼁する。

$\mathrm{t}:$ 世代数,

a : ホ去接合体の間の差として求めた遺伝子の効果, $\mathrm{q}$ ：望ましい遺伝子の頻度，

$\phi(a, q) ： a$ と の同時分布,

$\mathrm{n}$ : 量的形質に関与し，分離している遭伝子の数 このように定義すると，第 $\mathrm{t}$ 世代までの道伝的改良量 $\mathrm{Rt}$ とその分散 V(Rt) は，つぎの式で求められる.

$R t=n \int_{a=0}^{\infty} \int_{q=0}^{1} a E\left[q_{t}-q \mid a, q\right] \phi(a, q) d a d q$ $\mathrm{V}(\mathrm{R} \mathrm{t})=\mathrm{n} \int_{\mathrm{a}=0}^{\infty} \int_{\mathrm{q}=0}^{1} \mathrm{a}^{2} \mathrm{~V}(\mathrm{q},-\mathrm{q} \mid \mathrm{a}, \mathrm{q}) \phi(\mathrm{a}, \mathrm{q}) \mathrm{dadq}$ この式を用いるときには，離散近似を行なう必要がある。 このモデルによれば，集団の各種の遺伝的な性暨を变化 させながら，それらの選抜反応への効果を詳しく检討で きる ${ }^{28)}$.この上うな基本的な研究の成果は，将来， $\mathrm{G}$ と $\mathrm{E} の$ 同時分布を用いる奏用的なモデルの発展に役立 つであろう。

\section{3. 現行の長期的な選抜反応の予測モデル}

現場での育種計画は, 世代の重複, 群による選抜の指 標や選抜強度の違いなどの複雑な要因を含んでいる。こ の上うな条件下では，特定の個体群からの遺伝子の伝達 を明らかにして選抜反応を予測する万法がとられている。 実際に，中核育種集団方式 ${ }^{33)}$ p discounted gene flow

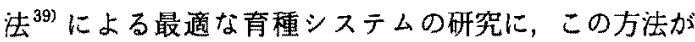
使われている，集団の性質の選抜による変化については 考慮していないが，実用的な方法である.

\section{V. 量的形質に関与する这伝子のメンデル 遗伝因子への分析}

MICHELMORE $^{40)}$ は，現在の計量遗伝学の発展に寄与 する研究分野としてつぎのものをあげた。
1. コンピュータシミュレーションによる数学的には 複雑だが実際的なモデルの研究67?.

2. モデルを立てるときの仮定が満たされないときに 生じる結果の偏りの推定と補正の研究.

3. 量的形質に影響をあたえる遗伝的要因のメンデル 遗伝因子への分析.

3.の研究分野で, 最近 LANDER らは, ロッドスコ ア（LOD）アナリシス ${ }^{41,70)}$ を使った新しい，効率の高 い方法を提示した．この方法の要点をつぎに引用する ${ }^{37}$.

i 番目の個体の表型価 $\phi_{i}$ と, 対立遗伝子 $\mathrm{A}$ と $\mathrm{B}$ をもつある座位の遺伝子型価 $\mathrm{g}_{\mathrm{i}}$ は，つぎの式の関係 をむつものとする.

$$
\phi_{i}=\mathrm{a}+\mathrm{bg}_{\mathrm{i}}+\varepsilon
$$

ただし， $g_{i}$ は B 遣伝子の数に等しい $(0,1)$ 表示変 量に变換されており， $\varepsilon$ は平均 0 , 分散 $\sigma^{2}$ のランダ 厶正規変量で， $\mathrm{a}, \mathrm{b}$ 上 $\sigma^{2}$ は未知のパラメターであ る. ここで b は想定した QTL (Quantitative Trait Locus）の一つの遗伝子の置換えによる表型価の変化 の推定値を表わす．1次回帰式のあてはめにより得ら れたパラメターの推定値（â, $\left.\hat{\mathrm{b}}, \hat{\sigma}^{2}\right)$ は，実は最尤推 定值 (Maximum Likelihood Estimates; MLEs) であり，観測されたデータが実現する確率 L $(a, b$, $\left.\sigma^{2}\right)$ を最大にするすのである.ここで，

$\mathrm{L}\left(\mathrm{a}, \mathrm{b}, \sigma^{2}\right)=\Pi_{\mathrm{i}} \mathrm{Z}\left[\left(\phi_{\mathrm{i}}-\left(\mathrm{a}+\mathrm{bg}_{\mathrm{i}}\right)\right), \sigma^{2}\right]$ であり, $Z\left(x, \sigma^{2}\right)=\left(2 \pi \sigma^{2}\right)^{-1 / 2} \exp \left(-\mathrm{x}^{2} / 2 \sigma^{2}\right)$ は 平均が 0 , 分散が $\sigma^{2}$ の正規分布の確立密度である. 最尤法では, 得られた MLEs は, マーカーに連鎖し ている QTL はないという仮定に対応する $b=0$ とい う条件のもとで求めた MLEs と比べられる. $b=0$ のときの MLEs は，容易に $\left(\hat{\mu}_{\mathrm{A}}, 0, \hat{\sigma}_{B 1}{ }^{2}\right)$ であるこ とがわかる.1つの QTL の存在の証放はロッドスコ アにより,つぎのように要約される.

$$
\mathrm{LOD}=\log _{10}\left[\mathrm{~L}\left(\hat{\mathrm{a}}, \hat{\mathrm{b}}, \hat{\sigma}^{2}\right) / \mathrm{L}\left(\hat{\mu}_{\mathrm{A}}, 0, \hat{\sigma}_{B 1}{ }^{2}\right)\right]
$$

これは，いま得られている一組のデータが実現する確 率が、QTL は存在しないと仮定したときよりる，存 在すると仮定したときの方がどれほど高まるかを示し ている. あしロッドスコアが前もって決めてある闌值 を超えたら，QTL が存在すると言える.

この方法を使って PATERSON らは泉)，トマトの果 実重量に関与する6つの QTLs (Quantitative Trait Loci）之，水溶性固形分率に関与する 4 つの QTLsな らびに，果実の $\mathrm{pH}$ に関与する $5 \supset$ QTLs の染色体 上の位置を，20-30 センチモルガンの正確度で決定した。

PIRCHNER は ${ }^{66)}$ ，これまでに家畜で知られている主働 遭伝子は偶然にみつけられたものが多いが，今後は新し 


\section{長期的な選抜の効果の予湘}

い統計的な方法を組織的に使って探すできであると述べ ている。

\section{VI. 今後の課題}

\section{$\mathrm{V}$ で述べたような遭伝的な機楎についての䂙究が進} めば，これまでは知ることのできなかった情報が手に入 り，それをコントロールしたり，利用したりすることが できるようになるであろう。

また, 計量遺伝学の分野では, 基本的な各種の遺伝的 要因の選抜効果への影算が, 動物実験とコンピュータシ ミュレーションならじに理論的研究により解明されつつ あり，今後一層これを発展させることが大切である。

これらの研究成果を土台として，現場で容易に入手で きるデーダを使った簡明・正確で，一般性の高い，長期 的な選抜効果の予測理論と方法をつくり出すことが必要 である。

\section{文献}

1）阿部猛夫，ホルスタイン牛の泌乳 3 形買のヘリタビリテ イおよび表型ならびに遗伝相関について，日畜会埌，30： 21-26. 1959.

2) AbplanalP, H., Linear heritability estimates. Genet. Res., Camb., $2:$ 439-448. 1961.

3) AVERY, P.J. and W.G. HILL, Variance in quantitative traits due to linked dominant genes and variance in heterozygosity in small populations. Genetics, 91 : 817-844. 1979.

4) Beardsley, J.P., R.W. Bratton and G.W. SALISBURY, The curvilinearity of heritability of butterfat production. J. Dairy Sci., 33 : 93-97. 1950.

5) BRADFORD, G.E. and L.D. VAN VleCK, Heritability in relation to selection differential in cattle. Genetics, 49 : 819-827. 1964.

6) Bulmer, M.G., The effect of selection on genetic variability : a simulation study. Genet. Res., Camb., 28 : 101-117. 1976.

7) Clayton, G.A. and A. Robertson, An experimental check on quantitative genetical theory. II. The longterm effects of selection. J. Genet., $55: 152-170.1957$.

8) Cochran, W.G., Improvement by means of selection. Proc. Second Berkeley Symp. on Math. Stat. and Prob., 449-470. 1951.

9) Crow, J.F. and M. KIMURA, Efficiency of truncation selection. Proc. Natl. Acad. Sci. USA., $76: 396-399$. 1979.

10) Dudley, J.W., 76 generations of selection for oil and protein percentage in maize. Proc. Int. Conf. Quant. Genet., 459-473. Lowa State Univ. Press. Ames. 1977.

11) Enfield, F.D., Long term effects of selection; The limits to response. Selection Experiments in Labora. tory and Domestic Animals. (Robertson, A. ed), 69-86. Commonwealth Agricultural Bureaux. Farnham Royal, UK. 1980.
12) FALCONER, D.S., Asymmetrical response in selection experiments. Proc. I.U.B.S. Symposium on Genetics of Population Structure, 16-41. 1953.

13) FALCONER, D.S., Introduction to quantitative genetics, 2nd ed. 170-223. Longman. New York, USA. 1981.

14) HARRIS, D.L., The general area: Setting the stage. Proc. Int. Conf. Quant. Genet., 39-45. Iowa State Univ. Press. Ames, USA. 1977.

15) Harris, D.L., Past, present and potential contributions of quantitative genetics to applied animal breeding. Proc. Int. Conf. Quant. Genet., 587-611. Iowa State Univ. Press. Ames, USA. 1977.

16) Henderson, C.R., Sire evaluation and genetic trends. Proc. of the Anim. Breeding and Genetics Symp. in Honor of Dr. J.L. Lush, A.S.A.S. and A.D.S.A., Champaign, IL. 1973.

17) Hill, W.G. and A. Robertson, The effect of linkage on limits to artificial selection. Genet. Res., Camb., 8 : 269-294. 1966.

18) HiLl, W.G. and A. RoBertson, Linkage disequilibrium in finit populations. Theoretical and Applied Genetics, 38 : 226-231. 1968.

19) Hill, W.G., Theory of limits to selection with line crossing. Biomathematics Vol. 1. Mathematical topics in population genetics. (KoJIMA, K. ed). 210-245. Springer-Verlag, Berline. 1970.

20) HILL, W.G., Estimation of genetic change. I. General theory and design of control populations. Animal Breeding Abstracts, $40: 1-15.1972$.

21) Hill, W.G., Estimation of genetic change. II. Experimental evaluation of control populations. Animal Breeding Abstracts, 40 : 193-213. 1972.

22) HiLl, W.G., Variation in response to selection. Proc. Int. Conf. Quant. Genet., 343-365. Iowa State Univ. Press. Ames. USA. 1977.

23) HILL, W.G., Design of quantitative genetic selection experiments. Selection Experiments in Laboratory and Domestic Animals. (RoBertson, A. ed) 1-13. Commonwealth Agricultural Bureaux. Franham Royal, UK. 1980.

24) HLL, W.G., Predictions of response to artificial selection from new mutations. Genet. Res., Camb., 40 : 255-278. 1982.

25) HiLL, W.G., Effects of population size on response to short and long term selection. Z. Tierzüchtg. Züchtgsbiol., 102 : 161-173. 1985.

26) HrLl, W.G., Population size ane design of breeding programmes. 3rd World Congress on Genetics Applied to Livestock Production, XII : 245-256. 1986.

27) Hill, W.G. and J. RAsbash, Models of long-term artificial selection in finite population. Genet. Res., Camb., $48:$ 41-50. 1986.

28) HrLl, W.G. and J. RASBASH, Models of long-term artificial selection in finit population with recurrent mutation. Genet. Res., Camb., 48 : 125-131. 1986.

29) HILl, W.G. and P.D. KEIGHTLEY, Interrelations of mutation, population size, artificial and natural selection. Proc. Second Int. Conf. Quant. Genet., 57-70. 
Sinauer Associates, Inc., Sunderland, USA. 1988.

30) IBE, S.N. and W.G. HILL, Transformation of poultry egg production data to improve normality, homoscedasticity and linearity of genotypic regression. J. Animal Breeding and Genetics, $105: 231-240,1988$.

31) JAMES, J.W., Response curves in selection experiments. Heredity, $20: 57-63.1965$.

32) James, J.W., The founder effect and response to artificial selection. Genet. Res., Camb., 16 : 241-250. 1971.

33) James, J.W., Open nucleus breeding system. Anim. Prod., 24 : 287-305. 1977.

34) Keighteey, P.D. and W.G. Hih, Directional selection and variation in finit populations. Genetics, 117 : 573-582. 1987.

35) KeightLeY, P.D. and W.G. HILl, Quantitative genetic variability maintained by mutation-stabilizing selection balance in finit populations. Genet. Res., Camb., $52: 33-43.1988$.

36) KIMURA, M. and J.F. CRow, Effect of overall phenotypic selection on genetic change at individual loci. Proc. Natl. Acad. Sci. USA. 75: 6168-6171. 1978.

37) LANDER, E.S. and D. BotSEIN, Mapping Mendelian factors underlying quantitative traits using RFLP linkage maps. Genetics, 121 : 185-199. 1989.

38) LindLEy, D.V., Regression lines and the linear functional relationships. J.R. Statist. Soc. Sup. 9:218244. 1947

39) McClingtock, A.E. and E.P. Cunningham, Selection in dual purpose cattle populations: Defining the breeding objectives. Anim. Prod., 18 : 237-248. 1974.

40) Michelmore, R.W. and D.V. Shaw, Character dissection. Nature, $335: 672.1988$.

41) Morton, N.E., Sequential tests for the detection of linkage. Am. J. Hum. Genet., $7: 277-318.1955$.

42）西田 朗 - 神部昌行 - 小宮山鐵朗 - 宮園辛男 - 阿部猛夫, 親子回㷌の線型性について．I．マゥスの体重の性およ び同腹兄弟数についての榑正法. 日畜会報，40:490-495. 1969.

43) Nishida, A., Some characteristies of parent-offspring regression in body weight of Mus Musculus at different ages. Can. J. Genet. Cytol., 14 : 293-303. 1972.

44) Nishida, A. and T. ABE, The distribution of genetic and environmental effects and the linearity of heritability. Can. J. Genet. Cytol., 16 : 3-10. 1974.

45）西田 朗・仁昌寺博・伊藤 蓠，交配後に行なう雌の能 力による切断選抜と交配した雨性平均能力による切断選 抜との選抜差に関する比较——豚の閉鎖群育種の一事例 に関する検討一一。 日本篗豚研究会誌, 14:125-132. 1977.

46) NISHIDA, A. and T. ABE, Effects of repeated selection on population mean, heritability and distribution of breeding value, Jpn. J. Zootech. Sci., 51 : 485-494. 1980.

47) Nishida, A. and T. ABE, Non-linear heritability and asymmetrical selection responses caused by skewed distribution of breeding value in selected population.
Jpn. J. Zootech. Sci., 51 : 495-500. 1980.

48) NISHIDA, A. and T. HAYASHI, A verification of a method to estimate the effect of repeated selection. Jpn. J. Zootech. Sci., 51 : 745-747. 1980.

49) Nishida, A., T. HAYAshi and Y. NAGAMINE, A theoretical model to evaluate effect of repeated selection on genetic correlation. Jpn. J. Zootech. Sci., 54 : 239-244. 1983.

50) NISHIDA, A, A theoretical model to estimate effects of repeated selection in closed population. Proc. Vth World Conf. Anim. Prod., 2: 41-42. 1983.

51) Nishida, A., T. Hayashi and Y. Nagamine, A theoretical model to predict the effects of repeated index selection in a closed population. Jpn. J. Zootech. Sci., $55: 350-355.1984$.

52) NishidA, A. and T. ABE, Theoretical prediction of long-term selection response. 3rd World Congress on Genetics Applied to Livestock Production, XII : 199204. 1986.

53) Nishida, A., K. MiUra and M. Satoh, A continuous distribution model to predict a long-term selection response taking the effects of reproduction into account. Proc. XVIII World's Poultry Congress, 323324. 1988.

54) Nishida, A., Y. Nagamine, K. Miura and $M$. SATOH, A continuous distribution model to predict a long-term selection response taking the effect of reproduction into account. Jpn. J. Zootech. Sci., 59 : 548-553. 1988.

55) Paterson, A.H., E.S. Lander, J.D. Hewitt, S. Peterson, S.E. Lincoln and S.D. Tanksley, Resolution of quantitative traits into Mendelian factors by using a complete linkage map of restriction fragment length polymorphisms. Nature, 335 : 721726. 1988.

56) Ptrchner, F., Finding genes affecting quantitative traits in domestic animals. Proc. Second Int. Conf. Quant. Genet., 243-249. Sinauer Associates, Inc., Sunderland, USA, 1988.

57) Rober tson, A., Optimum group size in progeny testing and family selection. Biometrics, $13: 442-450$. 1957.

58) Robertson, A., Progeny testing dairy bulls at different management levels. Anim. Prod., 2 : 141-152. 1960.

59) ROBERTSON, A., A theory of limits in artificial selection. Proc. Roy. Soc. London, B, 153 : 234-249. 1960.

60) ROBERTSON, A., Inbreeding in artificial selection programmes. Genet. Res., Camb., 2 : 189-194. 1961.

61) Robertson, A., A mathematical model of the culling process in dairy cattle. Anim. Prod., 8: 95-108. 1966.

62) RoBERTSON, A., A theory of limits in artificial selection with many linked loci. Biomathematics Vol. 1. Mathematical topics in population genetics. (KoJIMA, K. ed), 246-288. Springer-Verlag, Berlin. 1970.

63) ROBERTSON, A., Some optimum problem in individual selection. Theoretical Population Biology, 1 : 120-127. 1970. 


\section{長期的な選拔の効果の予測}

64) ROBERTSON, A., The non-linearity of offspring-parent regression. Proc. Int. Conf. Quant. Genet., 297-304. Iowa State Univ. Press., Ames, USA. 1977.

65) Robertson, A., Artificial selection with a large number of linked loci. Proc. Int. Conf. Quant. Genet., 307-322. Iowa State Univ. Press., Ames, USA. 1977.

66) RoBertson, A., The effect of selection on the estimation of genetic parameters. Z. Tierzüchtg. Züchtgsbiol., 94 : 131-135. 1977.

67) ROBERTSON, A., The contribution of computer studies to selection theory, Selection Experiments in Laboratory and Domestic Animals, 17-20. Commonwealth Agricultural Bureaux. Franham Royal, UK. 1980.

68) Robertson, A., The analysis of long term selection experiments. 3rd World Congress on Genetics Applied to Livestock Production, XII : 141. 1986.

69) Rönningen, K. A method for the estimation of appropriate selection intensity from skewed distribution. Acta Agric. Scand., 26 : 82-86. 1976.

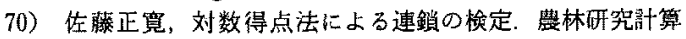
センター報㕰，A $24: 1-30.1988$

71) TAKedA, H., A. Nishida and A. TAKeBe, A geneassumed model to predict the long-term selection response taking account of the change in genetic properties from parents to off spring. Jpn. J. Zootech. Sci., 59 : 554-559. 1988.

72) Younc, S.S.Y., Computer simulation of directional selection in large populations. I. The programme, the additive and dominance models. Genetics, $53: 189-205$. 1966.

73) ZENG, Z.B. and W.G. HILL, The selection limit due to the conflict between truncation and stabilizing selection with mutation. Genetics, 114: 1313-1328. 1986. 